\title{
Challenges of Ethnic Representation in Ethiopia and the Need for Reform
}

Beza Dessalegn *

\begin{abstract}
Although the Ethiopian federal dispensation legitimizes political participation based on ethnic identity, the arrangement, both through design and political practice, has led to the skewed representation of ethnic groups. The article examines these challenges and argues that in addition to the existing electoral system, difficulties pertaining to the holding of free and fair elections, ethnic voting, the role of political parties and majoritarian decision-making procedures have severely undermined the effective political participation of ethnic communities. Moreover, the manner in which electoral constituencies are formed largely benefit the politically and numerically dominant ethnic group thereby undermining the representation of ethnic minorities. Yet, in some cases, notwithstanding the existence of ethnic groups with numerical ascendancy within an electoral constituency, the political practice ensures that a 'favored' ethnic group, despite being a numerical minority, is made the political majority. In the veil of these obstacles, it is contended that a mere change in the electoral system alone, without due consideration to the aforementioned factors, cannot bring a full-fledged solution to the underlying problems the political system is facing.
\end{abstract}

\section{Key terms}

Ethnic representation $\cdot$ Ethno-federalism $\cdot$ Electoral constituencies ·

Ethnic minorities $\cdot$ Ethiopia

DOI http://dx.doi.org/10.4314/mlr.v12i1.1

Received: 17 March 2018

Accepted: 7 September 2018

This article is licensed under a Creative Commons Attribution-NonCommercialNoDerivs (CC BY-NC-ND)

\footnotetext{
* Beza Dessalegn (LLB, LLM, PhD); Assistant Professor at Hawassa University, College of Law and Governance, School of Law. I am grateful for my colleagues Nigussie Afesha and Gosaye Ayele for their constructive comments on an earlier draft of this paper. I am also indebted to the two anonymous reviewers for their comments and suggestions, which has helped improve this article. Email: bezadesy@yahoo.com
}

Frequently used acronyms:

FPTP First-past-the-post (electoral system)

NEBE National Electoral Board of Ethiopia

PR Proportional Representation (electoral system) 


\section{Introduction}

From the very inception, the architects of Ethiopia's ethno-federalism promised a multiparty democracy ${ }^{1}$ and, vowed to undertake free and fair elections so that the hitherto marginalized minorities, not only administer themselves in their defined territories, but also participate effectively at federal and regional levels. ${ }^{2}$ To this end, both the Federal Democratic Republic of Ethiopia (FDRE) Constitution and the electoral law legalized a multiparty system. The plurality system of first-past-the-post (FPTP) was chosen as the best available route for guaranteeing equitable political participation. ${ }^{3}$

Based on this assumption, five rounds of general elections have been undertaken since the transitional period. The incumbent Ethiopian Peoples Revolutionary Democratic Front (EPRDF) and its affiliates vehemently argue that multiparty democracy has been taking root and ethnic groups are being effectively empowered through these elections. However, its detractors dismiss these claims by accusing the government of, inter alia, setting up a multiparty politics, which it never intended to implement and employing exclusionary politics that stifles the genuine empowerment of ethnic communities.

In the face of these accusations and counter-accusations, EPRDF and its affiliates have a (near) total control of the available political space at federal and regional levels. The narrowing down of the political space, among others, has resulted in an unprecedented level of mass protests immediately after the conclusion of the 2015 general elections. EPRDF quickly blamed the absence of opposition voices on the electoral system and announced its commitment to make adjustments -a change from FPTP to a mixed electoral system. Of course, a number of previous researches have also argued that in an ethnically diverse polity such as Ethiopia, where there exists a long history of competing ethnic nationalisms, the winner takes all approach does not seem to be a good choice in trying to ensure the equitable representation of ethnic communities. ${ }^{4}$

In view of this, this article investigates the impacts of other important elements such as the holding of democratic elections, the role of political parties, the impact of ethnic voting, majoritarian decision making procedures and the less explored impacts of the manner in which electoral constituencies

\footnotetext{
${ }^{1}$ See The Transitional Period Charter of Ethiopia, Peaceful and Democratic Transitional Conference of Ethiopia, Negarit Gazeta, 50 ${ }^{\text {th }}$ Year, No $122^{\text {nd }}$ July 1991, Article 1(b).

${ }^{2}$ Ibid, Article 2; the corresponding article to this charter is Article 39 of the FDRE Constitution, which also envisages for the self-rule and shared-rule rights of the country's ethnic groups or to use the constitutional term 'nations, nationalities, and peoples'.

3 Proclamation No 532/2007, The Amended Electoral Law of Ethiopia Proclamation, Federal Negarit Gazeta, 13th Year, No. 53, Addis Ababa, 25th June 2007, Article 25.

${ }^{4}$ See infra notes 19 and 20.
} 
are carved out. I argue that a change in the electoral system alone cannot bring tangible solutions to the challenges that are being faced by the political system.

By examining the overall situation at the federal level and selected three regions of Benishangul Gumuz (BG), Southern Nations Nationalities and Peoples (SNNP) and Oromia, the paper seeks to assess the challenges of ethnic representation in Ethiopia. The analysis is based on the federal and regional constitutions, the electoral law, and primary data gathered from the National Electoral Board of Ethiopia (NEBE). The choice of these regions is based on the following two legal and political considerations.

First, these regions present a different set of ethnic majority-minority relationships. Benishangul Gumuz has constitutionally dichotomized the regional population into indigenous and non-indigenous favoring the former (which together account for a slight 50+1 numeric majority) in many aspects of political empowerment. Yet, the non-indigenous communities, not only account for an almost half of the total population, but also dominate some electoral constituencies. On the other hand, the SNNP region has a unique challenge of ensuring equitable representation for 55 ethnic groups, none of whom are a $50+1$ majority at the regional level, even if some are both political and numerical majorities in their defined zones and liyu woredas. Despite the political and numerical dominance of ethnic Oromos, in the region of Oromia, it is also a host to one of the largest number of both territorial and non-territorial regional minorities.

Second, although determining and the setting up of electoral constituencies is the exclusive competence of the House of Federation ${ }^{5}$ (based on a study by the NEBE), the three regions have (for the purpose of conducting regional elections) used different ways in organizing their functioning electoral constituencies. Moreover, the three regions present a different form of political practice when it comes to the political participation of ethnic communities. While Benishangul Gumuz is ruled by an affiliate to EPRDF constituted only out of the indigenous nationalities, a member party of EPRDF but having allegiance only to a single ethnic group governs Oromia. Even if SNNP (like Oriomia) is ruled by a member party to the EPRDF, the regional ruling party has a unique onerous task of ensuring the representation of its diverse ethnic communities.

The first section of this article examines the political landscape of ethnofederalism in the wake of and after 1991. The dilemma between inclusion and exclusion in relation with ethnic representation in an ethnically diverse polity is examined in the second section. The third and fourth sections respectively deal with the criteria for setting up the electoral constituencies and the outcome of

\footnotetext{
${ }^{5}$ Proclamation No. 532/2007, Article 20(1)(e).
} 
the electoral constituencies in SNNP, Benishangul Gumuz and Oromia. The last section reflects upon the way forward.

\section{The political landscape in the wake of ethno-federalism: 1991 and after}

The post 1991 setup led to the proliferation of different, mainly ethnic based, political parties. This was relatively an unprecedented move in comparison to the Derg regime, where only a single party was allowed to operate in the political landscape. Yet, in what can be described as continuity, EPRDF coming from a hardcore Marxist-Leninist past ${ }^{6}$ - strictly pursued the Leninist concept of a vanguard party, whereby other competitors were not allowed on the same political scene. ${ }^{7}$

After 1991, EPRDF, arguably, declared a new frontier in the management of Ethiopian politics. The new paradigm was the hub of ethnicity, ${ }^{8}$ which required the body politic of the country to revolve around it. Affirming to this and in what appeared to be the widening of the political space, the Transitional Period Charter was declared in July 1991. Although the Charter was drafted by a wide array of ethnic based political organizations, resulting in the subsequent formation of many ethnic based and some multiethnic political organizations, the fact of the matter was most of these parties were carefully summoned and directed by EPRDF. ${ }^{9}$

Since the transitional period up to now, the political landscape has, therefore, never been short of a plethora of parties running around the political field. ${ }^{10}$ But the major point of concern was -how many of these parties had independent existence without any form of patronage from the EPRDF. As many spectators of Ethiopian politics agree, to the exception of the 2005 general elections, in all of the conducted elections, EPRDF was only in a race against itself. ${ }^{11}$

During the transitional period, two elections took place -the 1992 regional and local elections, and the 1994 elections to the Constituent Assembly. The outstanding result of these two elections was the withdrawal of many parties

\footnotetext{
${ }^{6}$ Kassahun Berhanu (2003), 'Party Politics and Political Culture in Ethiopia', in M.A. Salih (ed) African Political Parties: Evolution, Institutionalization and Governance, Pluto Press, p. 120.

${ }^{7}$ Merera Gudina (2011), Ethiopia: From Autocracy to Revolutionary Democracy, 1960s2011, Chamber Printing House, p. 156.

${ }^{8}$ See for instance, Article 2 of the Transitional Charter.

${ }^{9}$ Kassahun, supra note 6, p. 119.

${ }^{10}$ For instance, from 1991 to 2002 , some 79 parties were registered with the NEBE. Kassahun, supra note 6, p. 124-125.

${ }^{11}$ Merera Gudina (2011), "Elections and Democratization in Ethiopia, 1991-2010" 5(4) Journal of Eastern African Studies 664, p. 670-673.
} 
from contesting the elections $-\mathrm{a}$ result that can be ascribed to the careful maneuver of EPRDF. ${ }^{12}$ Consequently, elections during the transitional period were neither competitive nor free and fair. ${ }^{13}$ When the 1995 general elections, which brought an end to the transitional government, were held, as Lyons observed, EPRDF emerged as the single dominant party in the political system. ${ }^{14}$

But during the 2005 general elections, things took an unparalleled twist. EPRDF, in part, bowing to national and international pressure, opened up the political space to an unprecedented level. ${ }^{15}$ The opposition parties were given access to the government controlled media and they campaigned far beyond their usual support base. By any standard, this was the most competitive election in the electoral history of the country.

However, serious flaws ensued immediately after the elections. ${ }^{16}$ (1) EPRDF declared itself as the winner of the election, way before the National Electoral Board of Ethiopia (NEBE) announced official results. (2) The prime minister declared a 'semi-state of emergency' banning all protests following the disputed elections. (3) Opposition leaders were divided between the propriety of joining and not joining the parliament. EPRDF eventually arrested those who did not join parliament, accusing them of threatening the constitutional order. (4) EPRDF stood on its two feet and subsequently proceeded to wipe out all opposition voices from the political arena.

The general outcome of this was the closure of all political space and the promulgation of various laws, ${ }^{17}$ which (by many) were considered as tools for

${ }^{12}$ Kassahun, supra note 6, p. 120

${ }^{13}$ See for instance, Sigfried Pausewang (1992), "Local and Regional Elections in Ethiopia 21 June 1992", Human Rights Report 1. Oslo: Norwegian Institute of Human Rights, University of Oslo.

14 Terrence Lyons (1996), "Closing the Transition: The May 1995 Elections in Ethiopia" 34(1), The Journal of Modern African Studies 121, p. 142.

${ }^{15}$ Merera, Elections and democratization, supra note 11, p. 671-672.

${ }^{16}$ For an in depth discussion on the 2005 general elections, see Jon Abbink (2006), "Discomfiture of democracy? The 2005 Election Crisis in Ethiopia and its Aftermath", 105(419) African Affairs 173; René Lefort (2007), "Powers -Mengist- and Peasants in Rural Ethiopia: The May 2005 Elections" 45(2) The Journal of Modern African Studies, 253.

${ }^{17}$ As Merera notes, between 2005 and 2010, the HoPR passed, among others, The Amended Electoral Law Proclamation No. 532/2007, Political Parties Registration Proclamation No. 573/2008, Freedom of the Mass Media and Access to Information Proclamation No. 590/2008), Anti-Terrorism Law Proclamation No. 652/2009, Registration and Regulation of Charities and Societies Proclamation No. 621/2009, Electoral Code of Conduct for Political Parties Proclamation No. 662/2009, which, he argues, are carefully designed to 
silencing any form of dissent. ${ }^{18}$ But this shutting down of the political space which saw EPRDF emerge as the absolute vanguard party in the 2010 and 2015 elections- was not without its consequences. In the wake of the 2015 general elections, unprecedented mass protests erupted, mainly in the regions of Oromia and Amhara. These protests, surfaced immediately after the government declared a hundred percent electoral victory, and this showed not only the awkward nature of the declared results, but also the seriousness of the grievances pertaining to lack of good governance, socio-economic inequality, and derailed ethno-cultural justice.

\section{Ethnic representation in an ethnically diverse polity: The enduring dilemma of inclusion and exclusion}

Among the three prominent electoral systems of majoritarian, proportional and mixed, Ethiopia has adopted a segment of the majoritarian system of FPTP, which requires the winner to gain minimal majority of votes (in single member constituencies) -both for elections to federal and regional parliaments. Many have engaged in the discourse as to which electoral system best suits this ethnically plural polity. ${ }^{19}$ It was the conclusion of several authors that equitable representation of ethnic communities in Ethiopia will be best served by a carefully tailored proportional representation (PR) electoral system. ${ }^{20}$

silence any dissenting voice before and after the 2010 general election. Merera, Elections and democratization, supra note 11, p. 673.

18 Adem Abebe (2011), "Rule by Law in Ethiopia: Rendering Constitutional Limits on Government Power Nonsensical", CGHR Working Paper \#1, Cambridge: University of Cambridge Centre of Governance and Human Rights, p.1-19. Adem states that by using these laws, the EPRDF manipulates the judicial system to lock dissenting voices behind bars.

${ }^{19}$ For instance, see, Yonatan Fessha (2009), "Ethnic Identity and Institutional Design: Choosing an Electoral System for Divided Societies" 42 Comp. \& Int'l. L. J. S. Afr. 323; Getachew Assefa (2014), Electoral System and Political Pluralism in Ethiopia: A Case for Reform in Gedion Timotheows and Helen Fikre (eds.), The FDRE Constitution: Some Perspectives on the Institutional Dimension, Ethiopian Constitutional Law Series, Vol VI, p. 7-8; Kassahun Berhanu and others (eds.) (2007), Electoral politics, Decentralized governance and Constitutionalism in Ethiopia, Addis Ababa University Press.

${ }^{20}$ Some have of course mentioned the mixed electoral system as the best alternative, see Gebremeskel Hailu Tesfay (2017), "Reforming the Ethiopian Electoral System: Looking for the best Alternative", Oromia Law Journal. Vol. 6 No.1, p. 1-28; Adem Kassie Abebe (2015), The Winner shall not Take it All: Proposals for Electoral Reform to Ensure Inclusive Political Representation in Ethiopia, available at:

$<$ http://www.constitutionnet.org/news/winner-shall-not-take-it-all-proposals-electoralreform-ensure-inclusive-political>, accessed on May 30, 2018. 
Yet, in the wake of the anti-government protests, EPRDF, under a simmering pressure negotiated with (select) opposition parties and announced that a consensus has been reached to change the electoral system from FPTP to mixed. ${ }^{21}$ In the face of this development, this article explores whether the lack of alternative (opposition) voices in the political arena, since 2005, was solely attributable to the adopted electoral system, or whether it can be compounded to other factors as well.

A careful observer of the 2005 elections, which by far was the most credible and competitive in the electoral history of the country, reckons that, even with the FPTP, a sizable number of opposition parties were able to win significant number of seats, both at the federal and regional legislative bodies. More specifically, in 2005, for elections to the House of Peoples Representatives (HoPR), leaving aside allegations of ballot fraud and vote rigging, the opposition, in total, won 174 seats out of the 547 seats. $^{22}$

Interesting was also the ability of some parties to win seats in the HoPR from constituencies located in regional states, which could normally be described as outside of their ethnic comfort zones. ${ }^{23}$ This fact was even more pronounced at the regional (state) councils. For instance, in the region of Oromia, out of a total of 537 seats of the state council, OPDO (Oromo Peoples Democratic Organization) won 387 seats (during re-election its number of seats rose to 399), the Oromo National Congress (ONC) won 105 seats (after re-election 96), Coalition for Unity and Democracy (CUD) won 33 seats (after re-election 27), Oromo Federalist Democratic Movement won 10 seats, and the Geda System Advancement Party won 2 seats. ${ }^{24}$ In the region of Benishangul Gumuz, out of

${ }^{21}$ See for instance, Ethiopia to shift to mixed electoral rule, <https://www.thereporterethiopia.com/article/ethiopia-shift-mixed-electoral-rule>, accessed on February 1, 2018.

${ }^{22}$ See Official Results of the May 2005 General Election, 'The National Electoral Board of Ethiopia (NEBE)', <http://www.electionethiopia.org/en/announcement/251-officialresults-of-the-23rd-may-2005-general-.pdf>, last accessed 19 April 2016.

${ }^{23}$ For example, CUD managed to win two seats in the region of Benishangul Gumuz out of the allocated 9 seats to the HoPR. Similarly, it won a number of seats to the HoPR from the region of Oromia. Although CUD was established as a non-ethnic party, many were skeptical of this and viewed CUD, even if implicitly, as a party dominated by Amharas.

${ }^{24}$ Composition of the Caffee during the five round elections (1995, 2000, 2005, 2010, and 2015), i.e., after the establishment of the region and after the promulgation of the FDRE Constitution (document on file with author). See also the pamphlet issued by the Office of the Speaker and the Secretariat of the Caffee of the National Regional State of Oromia, document on file. 
the 99 seats, the region's ruling party won 86 seats, CUD won 11 seats, and independent candidates won the remaining two seats. ${ }^{25}$

Before considering this result in light of the electoral system, it is important to assess the manner of representation of ethnic communities. Non-indigenous ethnic minorities are neither represented at the HoPR from their place of residence, ${ }^{26}$ nor are they represented at the regional (state) councils. ${ }^{27}$ One is, therefore, forced to ask whether the constitutional architecture, present both at the federal and regional levels, ordains the representation of ethnic specific groups in the HoPR and respective regional councils.

The FDRE Constitution states that members of the HoPR shall be representatives of the Ethiopian people as a whole,${ }^{28}$ and a similar expression is found in the subnational constitutions. However, a holistic interpretation of the federal and the regional constitutions reveals that the design -coupled with the political practice- envisions ethnic representation as the preferred form of representation. ${ }^{29}$

The FDRE Constitution clearly states that "all sovereign power resides in the Nations, Nationalities and Peoples of Ethiopia". ${ }^{30}$ It further contends: "their sovereignty shall be expressed through their representatives". ${ }^{31}$ Noting that sovereign power of the state is exclusively vested in the Nations, Nationalities and Peoples of Ethiopia, ${ }^{32}$ and that their sovereignty is expressed through representatives elected to show the ethnic composition of the state, it will be hard to argue that representation to the HoPR is non-ethnic. It should also be remembered that the ethno-federal arrangement has formed 9 regions heavily

${ }^{25}$ Document from the secretariat of the regional state council on the $3^{\text {rd }}$ round composition of the regional parliament declares the number of non-indigenous representatives as 16 . Another source indicates that BGPDUF took 85 seats out of the 99 seats. The rest was shared between Coalition for Unity and Democracy (CUD), Ethiopian Berta People's Democratic organization (EBPDO) and independent candidates. CUD won 11 seats while EBPDO won 1 seat and independent candidates took 2 seats. See,

<http://www.africanelections.tripod.com/et_2005state.html\#Benishangul>, accessed 12 April 2015

${ }^{26}$ For instance, in the region of Oromia, despite the presence of millions of Amharas, there is no ethnic Amhara representative at the regional council in the 2015 elections. Nor are Amharas represented to the HoPR from Oromia region.

${ }^{27}$ In the SNNP region, for example, in the 2015 elections, the 55 indigenous ethnic groups occupy the state council alone despite the presence of hundreds of thousands of Amharas and Oromos within the region.

${ }^{28}$ See Article 54(4) of the FDRE Constitution.

${ }^{29}$ For the distinction on theories of ethnic representation, see Hanna F Pitkin (1967), The Concept of Representation, University of California Press, p. 60-91.

${ }^{30}$ Article 8(1) of the FDRE Constitution.

${ }^{31}$ Article 8(3) of the FDRE Constitution.

${ }^{32}$ See Article 8(1) of the FDRE Constitution. 
carved along ethnic criteria. Noting that this has (both numerically and politically) created ethnically empowered groups in the regions and representation to the HoPR, which normally is constituted from the regions, with strict language proficiency requirement for candidates to stand for elections,${ }^{33}$ it should not be strange if representation to the HoPR is a reflection of this ethnic setup.

As a matter of political practice, since the reorganization of the country into ethnic federation, EPRDF has largely sought to perpetuate ethnic representation, both at the federal and regional legislative bodies. For instance, at the HoPR, Oromo representatives exclusively represent Oromia, while Benishangul Gumuz selects representatives exclusively mirroring the indigenous nationalities. To date, at least on official accounts, regions being represented by a representative not from the dominant ethnic group or recognized indigenous ethnic minority is unheeded in EPRDF's political practice.

Likewise, the makers of the regional state constitutions, arguably, seem to have envisioned their respective constitutions to ensure the exclusive control of their political space to the regionally empowered ethnic group/s. ${ }^{34}$ In fact, at the regional level, there is a direct link between the right to self-determination, which is reserved only for the regionally empowered group/s, and sovereign power of the region. Yet, as the 2005 elections have shown (and as will be discussed further down), the above intention/assumption of the Constitution makers might not entirely hold true if the electorate decides to vote along ideological rather than ethnic lines,.

Under these circumstances, a question would arise whether a mere shift to a mixed electoral system can significantly change the realities, where the country,

\footnotetext{
${ }^{33}$ Under the current rule of representation, each region has a fixed number of constituencies matching the number of seats at the HoPR. Accordingly, Tigray has 38 Constituencies (out of which 2 are special constituencies), Afar has 8 constituencies, Amhara has 138 constituencies (out of which 1 is a special constituency), Oromia 179 constituencies, Somali 23 constituencies, Benishangul Gumuz has 9 constituencies (out of which 2 are special constituencies), SNNP has 123 constituencies (out of which 15 are special constituencies), Gambella has 3 constituencies (out of which 1 is a special constituency), Harari has 2 constituencies (out of which 1 is special constituency), Dire Dawa 2 constituencies, and Addis Ababa 23 constituencies. National Electoral Board of Ethiopia GIS Unit (2007), “The 547 Constituencies of The House of Peoples Representatives of Ethiopia", document on file. For a wider discussion into the language proficiency requirement, see Beza Dessalegn (2013), "The Right of Minorities to Political Participation under the Ethiopian Electoral system" 7(1) Mizan Law Review 67, pp. 67100.

${ }^{34}$ In some circumstances, some regions have made it possible for recognized indigenous ethnic minorities to have a say in the body politic of the regions.
} 
by design, gives a head start to ethnic representation of the dominant group and importantly where it has not been able to hold free and fair elections to the satisfaction of all. In this respect, serious questions could also be raised on the positive outcome of the recent negotiation regarding changing the electoral system.

The core of this agreement is: seats at the HoPR will be occupied using the mixed electoral system ${ }^{35}$ where $80 \%$ of the seats are to be won by using the FPTP whereas the remaining $20 \%$ of seats will be occupied using the PR system. ${ }^{36}$ First, if $80 \%$ of the seats are going to be occupied using the FPTP system, it means there is no significant shift. Since it is a political party with the greatest number of seats that will be entitled to form a government ${ }^{37}$ in a country where holding free and fair elections has not been made to the satisfaction of all, a party which wins 80 percent of the seats at the HoPR will be able to form parliament without any support from other parties holding the remaining 20 percent of the seats. If the espoused electoral system is not going to encourage inter-party negotiations and coalition formations between parties with differing ideologies, it is hard to see any significant modification. To make matters worse, those opposition voices that might secure the remaining seats through the PR system, under a system of simple majoritarian democracy, will simply have a window-dressing role. ${ }^{38}$

Coming back to the previous issue, in an ethno-federal setup, how the electorate votes (either through simple ethnic contours or by evaluating party programs) for political candidates is also very crucial. It is evident that the FPTP electoral system has not fared very well in equitably empowering ethnic groups in Ethiopia. ${ }^{39}$ But, one may doubt whether an electoral system can bring any

\footnotetext{
${ }^{35}$ Nevertheless, in a country like Ethiopia adopting the mixed electoral system where seats are allocated on the basis of a combination of electoral systems runs the risk of overwhelming, both the NEBE and the electorate, because it is; (i) comparatively complicated and difficult to administer and (ii) quite confusing for the electorate.

${ }^{36}$ Ethiopia to shift to mixed electoral system, supra note 21 . It is also not entirely clear from the negotiations on whether regional councils will follow suit or a different electoral system can be adopted for elections at the regional level. Of course, the Constitution is very clear on this matter as enacting laws regarding elections is the power of the federal government and therefore what is decided at the federal level will be followed at the regional level. See Article 55(2)(d) of the FDRE Constitution. Yet, as the diversity of the regions attests and noting of the significant differences between the regions themselves regarding the level of their regional ethnic diversity, leaving the power of legislation regarding elections to the federal government alone seems a little bit ill advised.

${ }^{37}$ Article 56 of the FDRE Constitution.

${ }^{38}$ See the discussion under section 5 regarding majoritarian decision-making procedures.

${ }^{39}$ Beza Dessalegn (2015), "Ethnic federalism and the effective political participation of minorities in Ethiopia", Paper presented at the First Graduate Conference on Peace,
} 
change where ethnic parties are the overwhelmingly available options and the electorate purely votes along ethnic rather than ideological lines.

In a political system where opposition voices are not allowed to disseminate their party programs, freely address the electorate and are only encouraged to function along ethnic lines, the electorate inevitably functions along ethnic contours. This seems to have been the case for elections after 2005, as EPRDF's ethnic coalition and its affiliates are the only voices present at the federal and regional levels. Yet, as the 2005 election has shown, not every voting will be carried out exclusively along ethno-nationalist lines if there is a conducive atmosphere, even in a system of ethnic federalism and despite the tendency of ethnic communities to vote for a representative from amongst themselves, ${ }^{40}$

Taking into consideration the number of ethnic political parties available for competition and the lack of a strong opposition party challenging the incumbent regime, one may argue for a shift in an electoral system for Ethiopia. ${ }^{41}$ Yet, a shift without genuine democracy, in which the electorate is able to freely articulate its choices, is not a guarantee for the effective political participation of ethnic communities. In an undemocratic process, since the choice of who should hold political power is not decided by the 'free will of the people', a shift in the electoral system alone will not bring about the desired result.

\section{Setting up the electoral constituencies: Under what standard criteria?}

In responding to the dilemma of empowerment and exclusion of ethnic groups in the political space since 1991, many have, inter alia, focused on the composition and impartiality of the $\mathrm{NEBE},{ }^{42}$ the influence of the electoral system, and to an extent, on language proficiency requirement for candidates to stand for elections. ${ }^{43}$ It is argued in this paper that despite the significant impact of the aforementioned points on the political participation of ethnic groups, the manner in which the electoral constituencies are formed -which has received

Federalism and Human Rights, Institute for Peace and Security Studies Addis Ababa University, p. 58-73.

${ }^{40}$ For an in-depth discussion regarding ethnic voting during the 2005 general elections, see, John Ishiyama (2010), "Ethnic Partisanship in Ethiopia", 16:3-4 Nationalism and Ethnic Politics, pp. 290-310; Leonardo R. Arriola (2007), "The Ethiopian Voter: An Assessment of Economic and Ethnic Influences with Survey Data" 3(1) International Journal of Ethiopian Studies 73, p. 73-90.

${ }^{41}$ Getachew, Electoral System and Political Pluralism in Ethiopia, supra note 19, p. 29-31.

${ }^{42}$ See for instance Merera, Ethiopia, supra note 7, p.168.

${ }^{43}$ See for instance Beza, The Right of Minorities, supra note 39. 
little (or no) attention-tremendously determines who is represented or excluded in a certain territory.

Electoral constituencies after 1991 were established as per Proclamation $64 / 1993$-a proclamation to provide for the electoral law of Ethiopia. ${ }^{44}$ According to its preamble, establishing the electoral constituencies was necessary in order to have the draft constitution ratified by a body (Constituent Assembly) elected through the direct participation of the people. ${ }^{45}$ The major purpose of the Constituent Assembly was therefore to ratify the draft constitution, which was adopted by the Transitional Period Council of Representatives. $^{46}$

Proclamation 64/1993 takes woredas as a basis, and the whole country was divided into electoral constituencies. ${ }^{47}$ Each constituency elects a single representative, ${ }^{48}$ which shall be composed of 100,000 inhabitants. ${ }^{49}$ This cutting edge of 100,000 seems to have been chosen because the draft constitution stated that the maximum number of seats to the HoPR was 550 and the 100,000 people

${ }^{44}$ Proclamation No. 64/1993, Electoral Law of Ethiopia, Negarit Gazeta of the Transitional Government of Ethiopia, 52 ${ }^{\text {nd }}$ Year, No 56, $23^{\text {rd }}$ August 1993, Addis Ababa.

${ }^{45} \mathrm{See}$ the Preamble of Proclamation No. 64/1993. As stated in the preamble, the Transitional Charter Article 11 envisages this from the very outset.

${ }^{46}$ Article 11 of the Transitional Charter. The Council of Representatives of the Transitional Period, pursuant to Article 7 of the Charter, was composed of (unelected) representatives of national liberation movements, political organizations, and prominent individuals having a maximum number of 87 members. As per Article $9(\mathrm{~g})$ of the Charter, the Council of Representatives established the Constitutional Commission, which was composed of experts' mandated to draw up a draft constitution (Article 10 of the Charter). With regard to the sequence of events, after the Constitutional Commission finalized the drafting process, it submitted it to the Council of Representatives for adoption (Article 10 and 11 of the Charter). The Council of Representatives adopted the draft constitution and then presented it for ratification to the Constituent Assembly, for which its members were elected pursuant to the terms and conditions set in the final draft of the constitution. It is based on this sequence of events that Proclamation 64/1993 was enacted to enable the election of the members of the Constituent Assembly.

${ }^{47}$ Proclamation No. 64/1993, Article 15(1). This, as the article envisages, was done without affecting regional boundaries. Regional boundaries at the time signified the 14 National/Regional Self-governments established as per Proclamation No. 7/1992, A Proclamation to Provide for the Establishment of National/Regional Self-Governments, Negarit Gazeta $51^{\text {st }}$ Year No. 2, Article 3.

${ }^{48}$ Proclamation No. 64/1993, Article 15(6).

${ }^{49}$ Id., Article 15(2). 
per constituency was found to be congruent with the then existing population size of the country. ${ }^{50}$

Normatively speaking, (i) if a woreda has 100,000 thousand inhabitants, it will automatically become an electoral constituency on its own. (ii) If a woreda's population is below 100,000, it will become an electoral constituency by joining adjacent woreda/s, with the view of reaching 100,000 population. (3) If a woreda's population is more than 100,000 , depending upon its size, it will be broken down into two or more 100,000-population categories thereby becoming two or more electoral constituencies. ${ }^{51}$

However, in demarcating the electoral constituencies, ${ }^{52}$ additional criteria were put in place. By taking the woredas that were setup before 1966 E.C, ${ }^{53}$ the woreda population was made to, as much as possible, overlap with the linguistic map of the country that was prepared by the Institute for the Study of Ethiopian Nationalities (ISEN). The purpose of combining the two was to create an overlap between ethnic identity and territory so that the electoral constituencies were really in concordance with the demands of the Nations, Nationalities, and Peoples to self-determination - in particular with their demands of self-rule. ${ }^{54}$

Based on this, the committee entrusted with drawing the electoral map of the country, by establishing which ethnic group is $50+1$ in each of (or a combination of) the woredas, drew the electoral constituencies. ${ }^{55}$ Yet, even though electoral constituency boundaries were initially based on woredas, they in fact are not identical to woreda boundaries. This pertains to two important reasons.

First, because it was impossible to find woredas that neatly fit the 100,000 population margin of an electoral constituency, major reformulations had to be made. The following table explains this dilemma of matching population size with the number of delegates. As the table indicates, an electoral constituency

${ }^{50}$ Interview with a senior GIS expert, National Electoral Board of Ethiopia, (Addis Ababa, 4 January 2016) who was also the member of the committee that worked on establishing the electoral map of Ethiopia.

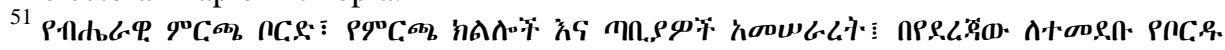

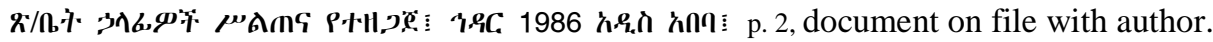

${ }^{52}$ The committee -entrusted with the task of drawing up the electoral constituencies- was mainly composed of professionals from the now defunct Institute for the Study of Ethiopian Nationalities (ISEN). See, Interview with a senior GIS expert, supra note 50.

${ }^{53}$ The reason given for this preference was: there was no adequate information as to the size and number of inhabitants of the new woredas (meaning woredas established after 1966 E.C) at the time. However, the committee entrusted with the task of drawing the electoral constituencies argued that the population and size of the new woredas were congruently

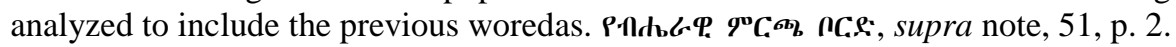

${ }^{54}$ Interview with a senior GIS expert, supra note 50.

${ }^{55}$ Ibid. 
can, for instance, be as small as having only a population size of 50,000 inhabitants or it could be as big as having 150,000 populations, but under both settings, constituencies are only entitled to a single representative.

\begin{tabular}{|c|c|}
\hline Population size & $\begin{array}{c}\text { Designated number } \\
\text { of representatives }\end{array}$ \\
\hline $50,000-150,000$ & 1 \\
\hline $150,001-250,000$ & 2 \\
\hline $250,001-350,000$ & 3 \\
\hline $350,001-450,000$ & 4 \\
\hline
\end{tabular}

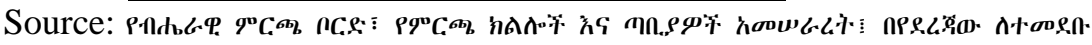

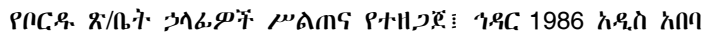

Second, this arrangement had to mandatorily deviate from woreda boundaries in trying to ensure that a certain ethnic group or a combination of ethnic groups (as is the case of indigenous nationalities in multiethnic regions) remain the fifty plus one group in electoral constituencies as well. For instance, in the regions of Amhara, Oromia, Afar, Tigray, and Somali, this has entailed an ethnic group, which constitutes fifty plus one of the populations of the region, to also constitute fifty plus one in the electoral constituencies. ${ }^{56}$

In finalizing the work, since the draft constitution stipulated for 550 seats (out of which at least 20 seats shall be reserved for 'minority nationalities and peoples'), 550 constituencies were set up. 525 of them were regular electoral constituencies and the remaining 25 were designated as special electoral constituencies. ${ }^{57}$ These special constituencies were needed for ethnic groups that have comparatively small numerical size (unable to fulfill the 100,000 threshold) compared to other ethnic groups, and as a result, they were unable to have an electoral constituency of their own. ${ }^{58}$

At this juncture, a new committee was established to determine these 'minority nationalities and peoples. ${ }^{59}$ The committee came up with more than thirty nationalities warranting special representation. ${ }^{60}$ In order to create an overlap with the identified nationalities and the remaining seats in the HoPR, a cutting edge of 10,000 populations was taken. ${ }^{61}$ Hence, an ethnic group to be considered as a minority nationality was required to have a population between

\footnotetext{
56 Ibid.

${ }^{57}$ Ibid

${ }^{58}$ See for instance, Proclamation No. 64/1993, Article 2(5).

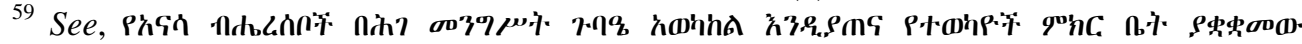
2.H.PQ. hoq,' GTC.' 18/05/86 E.C, document on file with author.

${ }^{60}$ Ibid.

${ }^{61}$ It is not clear what objective criteria were used to arrive at these cutting edge numbers.
} 
10,000 and 50,000. Based on this, their number was reduced from more than thirty to 22 . This meant 525 representatives elected from regular constituencies plus 22 representatives elected from special constituencies for a total of 547 seats at the Constituent Assembly.

A number of problems have surfaced following this approach. First, the electoral constituencies that were prepared for electing the members of the Constituent Assembly are still being used even after the approval of the Constitution and the high increase in the population size of the country. Apart from this, the regions, for various reasons, have rearranged their administrative boundaries, which have a significant impact on the electoral constituencies. ${ }^{62}$ As a result, elections since then are being conducted by taking, so to say, a middle ground between the two. ${ }^{63}$

The electoral law, which is currently in force -Proclamation No. 532/2007sets forth a new standard. Unlike previous electoral laws, ${ }^{64}$ it does not ordain the establishment of electoral constituencies based on fixed number of populations. Rather, the number of constituencies is to be determined based on the population census of the country. ${ }^{65}$ Since the FDRE Constitution fixes the number of seats to a maximum of 550, Proclamation No. 532/2007 does not change the number of seats at the HoPR if there is an increase in population. It rather allows changes in the number of population in an electoral constituency as the latter can only be changed through a constitutional amendment.

The NEBE in its recommendation to the HoF for updating the electoral constituencies calculated the population of an electoral constituency by dividing the total population of the country (based on the 2007 population census, i.e., $73,918,505$ ) by the total number of regular electoral constituencies (i.e., 525). ${ }^{66}$ It then recommended that each electoral constituency be composed of approximately 141,000 people. ${ }^{67}$ Based on this calculation, it recommended a change in the number of constituencies (seats) allocated to each region. For

\footnotetext{
${ }^{62}$ The prominent reason for this was the rearrangement of regional as well as sub-regional boundaries as a result of referendum outcomes in territories contested between two ethnic groups.

${ }^{63}$ Interview with a senior GIS expert, supra note 50.

${ }^{64}$ This includes Proclamation No 111/1995, A Proclamation to Make the Electoral Law of Ethiopia Conform to the Constitution of the Federal Democratic Republic of Ethiopia, Negarit Gazeta, 54th Year, No. 9, 23rd February 1995. It shares similar words with Proclamation No. 64/1993, with regard to the establishment of electoral constituencies.

${ }^{65}$ See, Proclamation No 532/2007, Article 20(1)(b).

${ }^{66}$ Letter written to the House of Federation from the National Electoral Board of Ethiopia regarding the updating of the electoral constituencies based on the national population census results, Megabit 8, 2001 E.C., document on file with the HoF, Addis Ababa.

${ }^{67}$ Ibid.
} 
instance, Tigray region will have its 38 regular constituencies reduced to 33 , Afar will have an increase from 8 to 10, Oromia from 179 to 193, Somali from 23 to 32 , etc. ${ }^{68}$ This recommendation has not been endorsed by the House of Federation $(\mathrm{HoF})^{69}$ and a new/updated electoral map of Ethiopia seems a highly politicized matter.

This recommendation does not, however, clarify how the special electoral constituencies are to be updated. Proclamation 532/2007 simply states that "minority nationalities which require special representation shall be determined on the basis of 'clear criteria' set in advance by the House of Federation". ${ }^{70}$ What is meant by 'clear criteria' is yet to be clarified by the HoF. Yet, during the current negotiations, it was reported that the government has agreed to an increase in the seats of the HoPR by 110 seats. ${ }^{71}$ The basis for the calculation in the course of raising the number of the seats and the task of identifying the seats into regular or special seats -not to mention how the constitutional amendment will take place- are yet to be clarified.

\section{Outcome of the established electoral constituencies: The regions of SNNP, Benishangul Gumuz and Oromia in context}

As already mentioned, the power of determining and setting up electoral constituencies (both for elections to the HoPR and regional councils) is the exclusive competence of the HoF (based on a study by the NEBE) ${ }^{72}$ For regional elections, the residual power of the regions is to determine the number of representatives from each electoral constituency. ${ }^{73}$ According to the electoral law, the number of representatives shall be decided by regional laws of the respective regions (although the English version of the same provision suggests that such shall be provided in/by regional constitutions). ${ }^{74}$ For instance, in the SNNP region, the number of representatives from each electoral constituency

\footnotetext{
${ }^{68}$ The number of regional electoral constituencies (in effect seats at the HoPR) is calculated by dividing the total population of a region to the population size of an electoral constituency.

${ }^{69}$ Interview with a senior GIS expert, supra note 50.

${ }^{70}$ Proclamation No 532/2007, Article 20(1)(d)

${ }^{71}$ See for instance, The Reporter, Understanding the Electoral Reform, $<$ https://www.thereporterethiopia.com/article/understanding-electoral-reform>, accessed March 11, 2017.

${ }^{72}$ Proclamation No. 532/2007, Article 20(1)(e); as discussed earlier, this article is yet to be implemented. Interview with a senior GIS expert, supra note 50.

${ }^{73}$ Proclamation No. 532/2007, Article 28(4).

${ }^{74}$ Ibid.
} 
for regional elections to the state council has been fixed by a separate regional proclamation. $^{75}$

The regions use the electoral constituencies already established for representation to the $\mathrm{HoPR}^{76}$ for representation to the state councils as well. But, as the evidence in the three regions (highlighted below) illustrate, the absence of separate electoral constituencies for regional elections has led to different interpretations.

For representation to the HoPR, the SNNP region has 123 electoral constituencies (108 regular and 15 special), ${ }^{77}$ which elect one representative from each constituency. However, for representation to the regional council (that has a total of 348 seats), the same constituencies are used with a different number of representatives. While a regular constituency, which has an assumed 100,000 population, elects three representatives, special constituencies elect one representative per constituency. ${ }^{78}$ Accordingly, the total number of seats at the regional council shall be 339 (i.e., three representatives from 108 regular constituencies and one representative from 15 special constituencies). Yet, the total number of members of the regional parliament is 348. It is not clear how the regional government legally defends this discrepancy, but increase in the number of representatives at the state council seems to have been undertaken to ensure that 55 ethnic groups -considered indigenous to the region- are represented in the state council. ${ }^{79}$

${ }^{75}$ Proclamation No. 105/2006, The Proclamation to Determine the Number of Members of the Councilors of the Southern, Nations, Nationalities and Peoples Regional State, Debub Negarit Gazeta, Awassa - Nov 19 ${ }^{\text {th }}, 2006$, Article 3(1).

${ }^{76}$ For representation to the HoPR, only one representative is elected from an electoral constituency. See Proclamation No. 532/2007 Article 28(3).

${ }^{77}$ Constituency Map of SNNP region at Zonal Level, document on file with author.

${ }^{78}$ Proclamation No. 105/2006, Article 3(1) \& (2); populous ethnic groups have the biggest number of electoral constituencies whereas numerically small nationalities have to depend on special representation mechanisms. In this case, Sidama zone has the largest electoral constituency, which is 19 followed by Wolayita zone 13. See also, Berhanu Gutema Balcha (2007), 'Restructuring State and Society: Ethnic Federalism in Ethiopia', PhD Thesis, Aalborg University, p. 195.

${ }^{79}$ Personal communication with the Head of Hawassa Branch National Electoral Board of Ethiopia (Hawassa, 30 May 2018); The NEBE branch head further argues that, although special constituencies can only elect a single representative to the regional parliament, in practice, some special constituencies elect more than one representative. It is due to this maneuver that the number of representatives exceeded the 339 mark. Still, the record, which details the composition of the members of the regional council, shows that the number of special constituencies exceeds 15 . [The composition of the representatives of the SNNP Regional Council, Fifth Round General Election (2015-2020), document on file with author]. It is not clear if this increase in the number of special electoral 
Out of the 55 indigenous ethnic groups, more than 30 have a population significantly less than $100,000 .{ }^{80}$ An ethnic group with a population of less than 100,000 is, therefore, not in a position to establish a regular electoral constituency of its own. Since, each zone and liyu woreda of the region is assigned with a fixed number of seats,$^{81}$ for those groups considered indigenous to a particular territory and that constitute numerical majorities in the regular electoral constituencies, ${ }^{82}$ their representation through the FPTP system is more or less guaranteed. For the remaining ethnic groups, that are unable to numerically dominate electoral constituencies and have their representatives elected, other mechanisms have to be used.

When an indigenous group is found to be a numerical minority in an electoral constituency, special constituencies are established. In the sub-regional administrations of Bench-Maji, Kaffa, South Omo, Gurage, Segen, and GamoGofa special constituencies are established to make sure that indigenous regional minorities are represented in the state council. ${ }^{83}$ For instance, in GamoGofa zone there are three special constituencies for the representation of the indigenous regional minorities Oyida, Zayisse, and Gidecho, allowing each of these ethnic groups to secure one seat in the state council. ${ }^{84}$

In circumstances where the aforementioned mechanism does not guarantee the representation of a desired/favored ethnic group, the other apparatus of ensuring its representation is the fielding of candidate/s exclusively from a certain ethnic group within an electoral constituency. For instance, in what seems to be a de facto recognition of Sidamas in Hawassa city, the region's ruling party only fields candidates from the Sidama ethnic group for Hawassa electoral constituency. The same is true for instance in Kembata-Tembaro zone,

constituencies has been sanctioned by the HoF and in turn by the NEBE or an ultra vires act of the regional government.

${ }^{80}$ See the population census results for the SNNP region, FDRE Population Census Commission, 'Statistical Report of the 2007 Population and Housing Census' (Central Statistical Authority 2007).

${ }^{81}$ Interview with, Head of Hawassa Branch National Electoral Board of Ethiopia (Hawassa, 11 February 2016); See also, Constituency Map of SNNP region at Zonal Level, supra note 77 .

${ }^{82}$ This conclusion is based on the following premises: First, electoral constituencies mainly use woredas as their bases; and second, a look at the composition of ethnic groups at the woreda level shows that indigenous groups constitute a numerical majority in almost all, save for some exceptions, woredas of the region. See FDRE Population Census Commission, 'Statistical Report of the 2007 Population and Housing Census' (Central Statistical Authority 2007) at the woreda level. (Electronic copy on file with author)

${ }^{83}$ Constituency Map of SNNP region at Zonal Level, supra note 77.

${ }^{84}$ For ethnic groups represented from special constituencies, see, Composition of the representatives of the SNNP regional Council, supra note 79. 
where the Donga ethnic group is a recognized indigenous minority. In the electoral constituency of Tembaro two candidates are from Tembaro while one candidate is from Donga, allowing the Donga indigenous minority to secure a seat in the state council.

Similar undertakings, however, with different intentions are used in Sheka, Gamo-Gofa and Gurage zones. For instance, Sheka zone (home to the indigenous ethnic group of Shekecho) is allotted with six seats at the regional council. However, an ethnic Kefficho (indigenous to Keffa zone) ${ }^{85}$ and Sheko (indigenous to Bench-Maji zone) have taken one seat each out of the allotted six seats. Likewise, Gamo-Gofa (for Aris of South Omo) and Gurage zone (for ethnic Hadiyas) have allowed ethnic representation at the regional council for ethnic groups not considered indigenous to the sub-regional administration. Nevertheless, it is unclear whether this is done in recognition to the principle of normative representation, despite the ethnic background of the representatives, or for purposes of political expedience -entirely dependent on the wishes of the region's ruling party.

There is also the language proficiency requirement. Since electoral constituencies in the SNNP are apportioned through zonal and liyu woreda administrations, the language proficiency requirement takes the language of the zonal or liyu woreda administration. ${ }^{86}$ It is therefore, under normal circumstances, impossible for a Gamo to get representation from Oyida constituency because he/she is unable to speak the Oyida language and vice versa. The language proficiency requirement ensures the representation of indigenous minorities despite their small numerical size in an electoral constituency.

This approach has resulted in the skewed representation of ethnic groups within the region. Of those ethnic groups having a population below 100,000, except for the Mareko in Gurage zone, all have a single seat at the regional council. For instance, from the South Omo zone, ${ }^{87}$ the Dime that has a population of 457 in the SNNP (and a countrywide total of 873) has one seat at the regional council just like the Malie with a regional population of 88,436 (and

${ }^{85}$ For instance, Kefficho is indigenous to the SNNP region but is not considered indigenous to the Sheka zone.

${ }^{86}$ ZeMelak Ayele (2012), "Decentralization, Development and Accommodation of Ethnic Minorities: The Case of Ethiopia" PhD Thesis, University of the Western Cape, 2012, p. 467. It should be noted that the working language of the region is Amharic.

${ }^{87}$ Based on the composition of the regional council available to this author, two indigenous ethnic groups of the South Omo Zone (Bacha and Brayle) and Majang of Sheka Zone do not have a seat at the state council. Composition of the representatives of the SNNP regional Council, supra note 79. 
a county total of 97,925). In contrast, the Mareko with a regional population of only 56,827 (and a country total of 64,272 ) occupy two seats at the regional council. ${ }^{88}$

In the Benishangul Gumuz region -home to the five indigenous groups of Berta, Gumuz, Shinasha, Mao and Como- for representation to the HoPR, nine electoral constituencies ( 7 regular and 2 special) electing one representative from each constituency are established. But for regional council elections, unlike the SNNP region, Benishangul Gumuz uses the woredas as electoral constituencies. ${ }^{89}$ The region is de facto composed of three zones of Assosa, Kamashi, and Metekel and Mao-Como special woreda. ${ }^{90}$ Assosa zone has seven woredas, Kamashi zone has five woredas and Metekel has seven woredas and Mao-Como special woreda is equated with a single woreda. Corresponding to these woredas, it means Assosa zone has seven electoral constituencies, Kamashi zone has five electoral constituencies, Metekel zone has seven electoral constituencies, Mao-Como has one electoral constituency.

The peculiar thing about these electoral constituencies is that the number of elected delegates (representatives) differs among these woredas. ${ }^{91}$ For instance, each of the electoral constituencies (woredas) in Assosa zone sends six representatives to the state council. Five electoral constituencies (woredas) of Kamashi zone send four representatives each, whereas out of the seven electoral constituencies (woredas) of Metekel zone, four woredas send four representatives each. Two woredas send five and six representatives respectively. As will be demonstrated later, by looking at the ethnic composition of the woredas and from the perspective of FPTP, it is possible to argue that a skewed representation exists in the Benishangul Gumuz region as well.

The region of Oromia has 179 regular electoral constituencies. ${ }^{92}$ Based on this, one delegate from each electoral constituency is elected for membership to the HoPR. The same electoral constituencies are again used for membership to

${ }^{88}$ See, Composition of the representatives of the SNNP regional Council, ibid.

${ }^{89}$ As mentioned earlier, the power to determine electoral constituencies is left to the HoF and the NEBE. But, it is not even clear to this author how Benishangul Gumuz government was able to decide on the determination of electoral constituency on its own.

90 De facto, because these zones do not have any constitutional backing from the region's constitution.

${ }^{91}$ In this regard, the region's ruling party, unlike the case of the SNNP region, decided the number of delegates during the dispute between the Berta and Gumuz, during the former's claim for separate statehood. And this is simply taken for granted for elections conducted including the recent regional election of 2015. Interview with, Law and Security Advisor, Benishangul Gumuz Regional State Council (Assosa 17 May 2016); Interview with Rural Association and Political Wing Head, Benishangul Gumuz Peoples Democratic Party (Assosa, 17 May 2016)

92 There are no special constituencies in the region of Oromia. 
the state council (Caffee). Similar to the SNNP region, three delegates from each of the 179 constituencies in Oromia region are elected to fill the 537 seats at the regional council. Representation to the regional council is based on the number of electoral constituencies present in each zone. Each electoral constituency (supposedly) has an assumed 100,000 population. ${ }^{93}$ This implies that an ethnic group (other than Oromos) with a population of less than 100,000 is not in a position to establish an electoral constituency of its own. ${ }^{94}$ Based on this, it is possible to argue that ethnic groups below this number will find it very difficult to secure representation under the FPTP. Even if a certain non-Oromo ethnic group becomes capable of being 100,000 or more within an electoral constituency, without positive gerrymandering, it will find it difficult to elect its own representative under the FPTP electoral system unless the ethnic group constitutes a 50+1 majority within the constituency.

The aforementioned ways of establishing electoral constituencies have the following implications. In the SNNP region Southern Ethiopian People's Democratic Movement (SEPDM) - outmaneuvering the electoral system- makes the ethnic representation of the 55 ethnic groups possible, even under the FPTP system through a careful use of the electoral constituencies coupled with political decisions undertaken by the region's ruling party. Primary in this regard is making use of special constituencies established for ethnic groups that are unable to establish an electoral constituency of their own. ${ }^{95}$ The second is employing the language proficiency requirement. The final and third mechanism is the decision by SEPDM in which a select ethnic group is fielded as a candidate in a particular electoral constituency. This, for instance warrants a decision to field a candidate who is indigenous to the region but not indigenous to the particular zone or liyu woreda. However, it still remains to be seen if this political practice will subsist once the incumbent of the region is not in a position to dominate the available political space. ${ }^{96}$

\footnotetext{
${ }^{93}$ Interview with a senior GIS expert, supra note 50.

${ }^{94}$ See, for example, a letter by the Zay People Democratic Organization, No 137/01/02 (29/06/2002 E.C), addressed to the HoF, on file with registrar of the HoF, Addis Ababa.

The party complained that the major hurdle behind the ZPDO in not winning a seat during elections, but it is rather the inability of the Zay people to establish an electoral constituency of their own as they are found dispersed in numerous electoral constituencies.

95 This is provided under Article 50(2) of the SNNP Constitution.

${ }^{96}$ A glimpse of this problem surfaced during the controversial 2005 election, whereby candidates from the non-indigenous communities won elections in some electoral constituencies, particularly in the multiethnic towns of the region (like Hawassa and Dilla), 'disrupting' EPRDF's carefully molded mirror representation of indigenous groups.
} 
The limits of these approaches are self-evident. (i) 55 ethnic groups, despite all being considered indigenous to the region, cannot be represented in the regional council outside of their ethnic homelands (zones or liyu woredas). ${ }^{97}$ (ii) There is no place for representation to groups which are considered nonindigenous within the region. (iii) The FPTP system significantly accelerates the dominance of the SEPDM by sidelining small parties, which cannot receive seats in proportion to their votes. This can be illustrated by the outcome of the 2015 elections to the state council, in which all the seats in the council were won by the SEPDM although there were 21 parties in the contest. ${ }^{98}$

In the region of Benishangul Gumuz, the impact of the setting up of the electoral constituencies coupled with the political practice has impacted ethnic representation in more or less similar ways. More specifically, in Metekel zone, ${ }^{99}$ in two of the woredas (Guba and Mandura), the Gumuz alone constitutes a 50+1 ethnic majority, whereas in two woredas of Wenbera and Bulen the combined presence of Gumuz and Shinasha constitute a 50+1 ethnic majority. In two woredas (Dangur and Dibate) no single ethnic group accounts for 50+1 of the woreda population. The combined presence of Agew Awi and Amhara in Dangur, Oromo and Amhara in Dibate, account for 50+1 population of the respective woredas. In Pawe woreda, however, Amharas constitute a convincing $50+1$ majority. ${ }^{100}$

In Kamashi zone, out of the five woredas, in Yaso, Sirba Abay, Kamashi and Agalo Meti the Gumuz constitute a 50+1 majority. In Belojiganfoye woreda no single ethnic group accounts for a 50+1 majority of the population. However, the combined presence of Amharas and Oromos constitute 50+1 majority. In Assosa zone, out of the seven woredas, in five of the woredas (Menge, Kurmuk, Sherkole, Oda Bilidigilu, and Homosha) Bertas constitute a 50+1 majority. However, in Assosa and Bambassi woredas no single ethnic group constitutes a $50+1$ majority of the population, but in both woredas the combined presence of Amhara and Oromo ethnic groups constitute a 50+1 majority. ${ }^{101}$

From the aforementioned figures, it is visible that out of Benishangul Gumuz's 20 woredas (electoral constituencies), an indigenous nationality alone

\footnotetext{
${ }^{97}$ The exceptions to this, as already outlined, are the situation in Gamo-Gofa, Sheka, and Gurage zones.

${ }^{98}$ National Electoral Board of Ethiopia, 'List of Political Parties and Independent Candidates that Competed in the 2015 General Election' (Addis Ababa 2015), document on file with the author.

${ }^{99}$ Even though there is no 50+1 majority ethnic group at the zonal level, the combined presence of the Gumuz and Shinasha constitute a 50+1 majority. See FDRE Population Census at the woreda level, supra note 80 .

${ }^{100}$ Ibid.

${ }^{101}$ Ibid.
} 
or the combined presence of two indigenous nationalities constitutes a 50+1 majority in 14 woredas. It can, therefore, be argued that this numerical superiority, whereby the indigenous nationalities enjoy $50+1$ dominance, arguably, gives them a head start under the FPTP. However, an argument can still be raised that several seats can be won (for regional council elections) in a single constituency, even though it is not numerically 50+1. Under normal circumstances, this gives opportunities to the non-indigenous minorities to win a number of seats even if an indigenous group or a combination of two indigenous nationalities dominate a constituency. A number of reasons could be raised to respond to the above assertion.

The first factor relates to the non-existence of a strong opposition political party, which challenges the region's ruling party in elections and submit potential candidates in each of the woredas advocating for the political rights of the non-indigenous communities. For instance, in woredas like Bambassi of Assosa zone, where the combined presence of non-indigenous groups accounts for the majority, Bertas occupy all the allocated 6 seats. ${ }^{102}$ Since there is no strong political party within the region exclusively established for the nonindigenous communities that presents candidates for electoral competition, ${ }^{103}$ the non-indigenous communities either do not vote or if they vote, they will only vote for the available indigenous candidate submitted by the region's ruling party - Benishangul Gumuz Peoples Democratic Party (BGPDP). ${ }^{104}$

Second, in the absence of strong opposition, the BGPDP, without a clear formula, submits non-indigenous representatives in some woredas and omits their presence in others. This is clearly visible in the technique the party uses towards ensuring the proportional presence of indigenous nationalities where they conjointly are a (numerical and political) majority. In such circumstances, since all indigenous nationalities run through one political party of BGPDP, the party apparatus carefully selects candidates to avoid splitting of votes amongst the indigenous nationalities. One common mechanism for this is, if for instance, in a woreda like Bulen (which has 6 delegates to the state council), where

${ }^{102}$ See, 'The composition of the Regional State Council of Benishangul Gumuz Region for 2015-2020', document on file with the author.

${ }^{103}$ In the 2015 elections, six parties including the region's ruling party took part. However, none of the five opposition parties were able to present significant competition against the region's ruling party. Interview with, Head of Assosa Branch National Electoral Board of Ethiopia (Assosa, 19 May 2016).

${ }^{104}$ However, during the contested 2005 elections, CUD, which was relatively active in the region, managed to win all the four seats allocated to Pawe woreda, 3 seats out of the 6 allocated to Assosa woreda, 3 seats out of the 6 allocated to Bambassi woreda, and 1 seat out of the 4 allocated to Dangur woreda. See, The composition of the Regional State Council of Benishangul Gumuz, supra note 102. 
Gumuz and Shinasha together constitute a numerical majority, the six representatives are apportioned between Gumuz and Shinasha. Accordingly, 4 candidates from Shinasha and 2 candidates from Gumuz are submitted by the BGPDP. This, however, is not replicated in woredas where the non-indigenous communities are found in a combined majority.

Third, even in woredas where the representation of the non-indigenous communities is permitted, the number of representatives to the regional council from that particular woreda is significantly less than the number of representatives from a woreda where indigenous nationalities are elected. For instance, in Pawe, Amharas constitute a numerical 50+1 majority. Pawe woreda can only send 4 representatives whereas woredas in Assossa zone are allowed to elect six representatives each. Even from Pawe woreda, which has an allocated 4 representatives to the state council, only 3 are ethnic Amharas and a Kambata fills the remaining seat. However, all of the four representatives run through the party ticket of the region's ruling party.

In the region of Oromia, the reality on the ground reveals that the region, despite being largely constituted by Oromos ( $88 \%)$, is also inhabited by diverse ethnic groups (accounting for $12 \%$ of the regional population). ${ }^{105}$ Yet, all the representatives of the state council are ethnic Oromos. ${ }^{106}$ Even though a clearcut statistical data is not available with regard to a $50+1$ majority in each of the 179 electoral constituencies, the numerical $50+1$ dominance of Oromos at the regional, zonal, and in many of the woreda levels implies that Oromos continue to constitute $50+1$ majority in the electoral constituencies as well. ${ }^{107}$ Emboldened by the manner of forming electoral constituencies and the exclusionary elements of the electoral law (such as its language proficiency requirement and FPTP), a region home to millions of non-Oromos, does not even give nominal representation to its non-indigenous communities, just like the region of Benishangul Gumuz.

\section{Westminster democracy in an ethnically plural society: Which way forward?}

Additional to electing representatives through the FPTP electoral system, according to the FDRE Constitution, all decisions of the HoPR are taken by a

105 Based on the FDRE Population Census Commission (2007), 'Statistical Report of the 2007 Population and Housing Census', Central Statistical Authority a total of 3,285,166 non-Oromos live in the region of Oromia.

${ }^{106}$ See, composition of the Caffee for the 2015 general election, supra note 24

${ }^{107}$ It should also be reckoned here that the electoral constituencies are carved out with the intention of making the indigenous group to constitute a 50+1 majority. 
(simple) majority vote of members present and voting. ${ }^{108}$ Decision-making procedures in the regional states also follow similar trends of majoritarian $(50+1)$ democracy. ${ }^{109}$ For what it is worse, the exercise of government power in the regional states has been elusive for their minorities. Typically, the (politically) dominant or majority ethnic group considers itself as the 'owner' of the regional state, threatening the individual as well as group specific rights of its minorities. ${ }^{110}$ As Lijphart repeatedly described, in plural societies simple majority rule, which sees the winner takes all practice, is both dangerous and undemocratic. $^{111}$ In fact, federalism, best functions in circumstances of consensus, where power is legitimately shared between different contending groups. $^{112}$

Yet, the Ethiopian ethno-federal setup has not put in place sufficient constitutional guarantees. Four factors, among others, can be noted in this regard. First, there are no power-sharing arrangements over and above legislative representation between the different ethnic communities in the executive, judiciary and other institutions like the police and the military. ${ }^{113}$ Despite the existence of Article 39(3) of the FDRE Constitution, which, arguably, provides for some sort of power sharing between contending groups at federal and regional levels, as Getachew rightly noted, the Constitution has not taken this provision further and supplemented it with clear rules and guidelines

${ }^{108}$ Article 59(1) of the FDRE Constitution; Decisions, which require special majority procedures under the FDRE Constitution, among others, are those warranting amendment of the Constitution and declaration of a State of Emergency.

109 See, for instance, Article 55 of the Somali Constitution, Article 56 of the SNNP Constitution, Article 58 of the Gambella Constitution, Article 55 of the Amhara Constitution, Article 56 of the Benishangul Gumuz Constitution, Article 53 of the Afar Constitution, Article 57 of the Harari Constitution, Article 59 of the Tigray Constitution and Article 52 of the Oromia Constitution. For a detailed discussion on decision-making procedures at the regional level in the context of the three case studies, see chapter five, six, and seven. However, the Harari case presents a slight deviation from other regions, for instance, when it comes to picking the President of the region, which is mandatorily supposed to be from the numerical minority Harari ethnic group.

${ }^{110}$ Assefa Fiseha (2016), "Intra-Unit Minorities in the Context of Ethno-National Federalism in Ethiopia", 3(1) Ethiopian Journal of Federal Studies 39, p. 40-41.

111 Arend Lijphart (1984), Democracies: Patterns of Majoritarian and Consensus Government in Twenty-one Countries, Yale University Press, p. 22-23.

112 Daniel J. Elazar (1992), Exploring Federalism, University of Alabama Press, p. 12; In fact, this is expressly provided under Article 39(3) of the FDRE Constitution.

${ }^{113}$ For a wider discussion on this matter, Getachew Assefa (2014), "Constitutional Protection of Human and Minority Rights in Ethiopia: Myth v. Reality" PhD Thesis, University of Melbourne, p. 79-88. 
to make it effective. ${ }^{114}$ Secondly, Ethiopia has no effective reserved (guaranteed) seats and quota systems for ethnic minorities, particularly, in legislative bodies (national, subnational or local parliaments) for the representation of minority groups, mostly, outside of electoral competition. As Verstichel explains, this is a mechanism, which does not only promote minority representation, but one that effectively guarantees their representation. ${ }^{115}$

Under Article 54(3) of the FDRE Constitution, 'minority nationalities and peoples' are guaranteed representation through reserved seats in the HoPR. 'Minority nationality and peoples', however, refers merely to those particular ethnic groups that do not have sufficient number of people that can make up an electoral constituency for representation to the HoPR. Thus, other requirements in the determination of minority status (such as the issue of non-dominance at the regional level) are not considered as legitimate grounds to warrant representation, which in effect means no guaranteed representation for regional minorities. And for those who are represented, as discussed earlier, the majoritarian decision-making procedure undermines their presence, since decisions will eventually be made by the majority of the day.

Another mechanism for increasing the influence of a minority is through a quota system. This is a policy of ensuring that a specified number or percentage of minority groups become members of, let us say a national or subnational parliaments, party lists, etc. ${ }^{116}$ For this, for instance, political parties may spontaneously or for electoral convenience allocate quotas for persons belonging to minorities among the candidates on their lists. ${ }^{117}$

In the case of Ethiopia, an informal quota scheme -without a legal framework- seems to run through the EPRDF party system. For example, party lists of EPRDF always consist of members of native identities when contesting in particular minority sensitive areas, like selecting an Agew candidate in areas where Agews are found in huge numbers within an electoral constituency. Yet, since this is done without adequate legal guarantees, EPRDF can take it away at any moment - leaving minorities at its mercy.

The third factor that needs attention relates to absence of veto power to minorities. In the constitutional design of some countries, minorities are given veto powers with respect to certain matters, which are considered to be of a

\footnotetext{
${ }^{114}$ Id., p. 80.

${ }^{115}$ Annelies Verstichel (2009), Participation, Representation and Identity: The Right of Persons Belonging to Minorities to Effective Participation in Public Affairs: Content, Justification and Limits, Intersentia, p. 412.

116 Thomas R Conrad (1976), "The Debate about Quota Systems: An Analysis" 20(1) American Journal of Political Science 135, 135-136.

${ }^{117}$ Verstichel, supra note 115, p. 397-398.
} 
particular concern to them. ${ }^{118}$ The justification behind veto rights is that the consent of minority representatives is necessary before going ahead with the enactment of certain legislation in parliaments. The minority veto can be either an absolute veto (which empowers minorities to utterly defeat a bill in some situations) or a suspensive one (which only challenges the majority of the day to reconsider its legislative choices). ${ }^{119}$ This, as Lijphart explains, may be applied either to all decisions or to only certain specified kinds of decisions. ${ }^{120}$ Veto rights, besides creating a sense of ownership of the state, also empower minorities to significantly influence decisions made at the center. Veto power is commonly understood as a valuable mechanism to shield the minority from the 'tyranny of the majority'. In Ethiopia, no veto rights are available for ethnic minorities at the federal or regional parliaments, which enable them to counter decisions affecting their interests.

The fourth factor in the absence of constitutional guarantees to minorities is related with lack of consultative mechanisms that aim to avert the dangers of majoritarian democracy. Consultative mechanisms are increasingly seen as a space in which minority political groups, civil society representatives and governmental bodies can interact, and where the views, concerns and interests of minorities can be effectively incorporated within the process of policy planning, implementation and evaluation. ${ }^{121}$

Minority consultative bodies are important for the effective participation of minorities in two dimensions. First, where minorities are not fully represented in elected bodies, their lack of co-decision making can be compensated through the process of consultation before decisions are taken. Second, even where minorities are represented, given their non-dominant position in the representative/elected bodies, consultative mechanisms often prove effective in transmitting the interests of minority constituencies into the legislative or political decision making process. ${ }^{122}$ Although these consultative mechanisms take on different functions in different contexts, it is asserted that their effective

${ }^{118}$ Solomon Dersso and Francesco Palermo (2013), 'Minority Rights' in Mark Tushnet and others (eds.), Routledge Handbook of Constitutional Law, Routledge, p. 166.

${ }^{119}$ Ibid.

${ }^{120}$ Arend Lijphart (1995), 'Self-Determination versus Pre-Determination of Ethnic Minorities in Power-Sharing Systems'. in Will Kymlicka (ed.), The Rights of Minority Cultures, Oxford University Press, p. 279.

${ }^{121}$ For a detailed account of minority consultative mechanisms and working procedures, see, Marc Weller (2010), 'Minority Consultative Mechanisms: Towards Best Practices'. in Marc Weller and Katherine Nobbs (eds), Political Participation of Minorities: A Commentary on International Standards and Practice, Oxford University Press 2010, pp. 479-502.

${ }^{122}$ Id., p. $478-479$. 
performance widely depends upon their inclusive representation, active participation and commitment among the minority representatives, as well as the availability of sufficient resources and their operation independent from political interference. ${ }^{123}$ Unfortunately, no such mechanisms exist in Ethiopia.

\section{Conclusion}

In ethnically plural societies like Ethiopia that seek to manage ethnic diversity, equitable representation of ethnic communities is very crucial. Ethiopia adopted the plurality system in order to ensure equitable ethnic representation, despite the clear anomaly it poses to ethnic minorities. In what seems to be recognition of this abnormality, there now appears a strong desire to move away from the plurality system.

While a change in the electoral system is long overdue, this article has shown that a simple shift in an electoral system without giving due attention to various concerns (that need to be addressed) will not be fruitful. These concerns include the holding of free and fair elections, the impact of ethnic voting, a constitutional design that facilitates ethnic representation, the role of political parties, and the widening of the political space. In the absence of these settings and where no change is made to the manner of establishing electoral constituencies and simple majority rules of decision making (at federal and regional legislative bodies), the desired outcome of having alternative voices that have meaningful influence will not be accomplished.

${ }^{123}$ Weller, Minority Consultative Mechanisms, supra note 121, p. 499. 